\title{
Comparison of full-fat corn germ, whole cottonseed, and tallow as fat sources for lactating dairy cattle
}

\author{
W. F. Miller, J. E. Shirley, E. C. Titgemeyer, ${ }^{1}$ and M. J. Brouk \\ Department of Animal Sciences and Industry, Kansas State University, Manhattan 66506-1600
}

\section{ABSTRACT}

Twenty-four multiparous Holstein cows $(124 \pm 39 \mathrm{~d}$ in milk; $682 \pm 72 \mathrm{~kg}$ of body weight) were used in 6 simultaneous $4 \times 4$ Latin squares to evaluate full-fat corn germ as a fat source for lactating dairy cows. Experimental diets were a control (containing $28 \%$ ground corn, $23 \%$ alfalfa hay, $19 \%$ wet corn gluten feed, and $10 \%$ corn silage, dry matter basis), and 3 diets with either whole cottonseed (WCS), tallow (TAL), or full-fat corn germ (FFCG) added to provide $1.6 \%$ supplemental fat. Cows were fed twice daily for ad libitum intake. Dry matter intake, milk yield, and energy-corrected milk did not differ among diets. Efficiency of milk production (energy-corrected milk/dry matter intake) was greater for cows fed WCS than for cows fed the control, TAL, or FFCG. Milk fat percentage from cows fed FFCG was less than that of cows fed WCS or the control, but was similar to that of cows fed TAL. Milk protein percentage was less for cows fed FFCG than for those fed the control. Total saturated fatty acids were less in milk from cows fed fat sources, and cows fed WCS and TAL had greater saturated fatty acids in milk than did cows fed FFCG. Unsaturated fatty acids were greater in milk from cows fed FFCG than in milk from cows fed the control, WCS, or TAL. The cis-9, trans-11 conjugated linoleic acid content was greater in milk from cows fed WCS, TAL, and FFCG than from cows fed the control, and it was greater in milk from cows fed FFCG than in milk from cows fed WCS or TAL. These results indicate that FFCG can be used effectively as a fat source in diets for lactating dairy cattle.

Key words: full-fat corn germ, conjugated linoleic acid, milk fat

\section{INTRODUCTION}

To support milk production in high-producing dairy cattle and maximize caloric intake, dairy producers must provide an energy-dense diet to the lactating dairy cow. Strategic use of cost-effective feedstuffs, such as coproducts, by dairy managers and nutritionists

Received February 10, 2009.

Accepted March 24, 2009.

${ }^{1}$ Corresponding author: etitgeme@ksu.edu influences the palatability of the diet, DMI, and nutrient content of milk. Energy density of the diet is often augmented by grains, such as corn, which increases the content of rapidly fermentable carbohydrates and predisposes the rumen to subacute or acute acidosis (Nocek, 1997; Pereira et al., 1999). Inclusion of fat increases the energy content of the diet and enhances the absorption of fat-soluble nutrients in support of high milk production without the negative effects associated with increased dietary starch. Fats can have deleterious effects on the rumen ecosystem when fed at levels that result in DMI depression (Grummer, 1988; Chilliard, 1993). Ruminal digestibility of nutrients may be unaffected by dietary fat addition if DMI is decreased, but nutrient digestibility may be decreased or shifted to the lower gut if DMI is not affected. In addition, fat percentage and fatty acid composition in milk may be altered by fat addition to diets for dairy cattle (Jensen, 2002). Thus, strategic selection of fat sources, based on fat content and fatty acid composition, is imperative to minimize ruminal disruption or to alter milk fat for a desired component such as conjugated linoleic acid (CLA). The selection of a supplemental fat source for use in diets for lactating dairy cows is generally based on its ability to improve production relative to cost. Full-fat corn germ (FFCG) traditionally used for corn oil production has some potential as a feedstuff when the corn oil market is devalued, but little or no information concerning its use in dairy cow diets is available. The full-fat corn germ used in this study was derived from the wet-milling process of corn. Dry milling of corn associated with ethanol production yields a germ product that contains less fat and typically becomes a component of distillers grains. The objective of our study was to determine the relative value of full-fat corn germ as a fat source for lactating dairy cattle, compared with the values of tallow (TAL) and whole cottonseed with lint (WCS).

\section{MATERIALS AND METHODS}

All procedures were approved by the Kansas State University Institutional Animal Care and Use Committee. 


\section{Experimental Design and Treatments}

Twenty-four multiparous Holstein cows $(124 \pm 39$ DIM; $682 \pm 72 \mathrm{~kg}$ of BW) were used in 6 simultaneous $4 \times 4$ Latin squares, with 28 -d periods, to evaluate FFCG as a fat source for lactating dairy cows. Cows were blocked into 6 groups of 4 on the basis of previous 305-d, twice-daily-milking, mature-equivalent milk yield, BW, and BCS. The first $14 \mathrm{~d}$ of each period was used for diet adaptation, with data from the last $14 \mathrm{~d}$ of each period used for statistical analysis. The control diet (Table 1) was formulated to meet nutrient recommendations for 651-kg cows producing $40.9 \mathrm{~kg}$ of milk daily (NRC, 2001). Experimental diets (Table 1) containing WCS, TAL, or FFCG were formulated to be isonitrogenous, isocaloric, and isolipidic on a DM basis. Whole cottonseed, TAL, and FFCG were included in diets at $9.44,1.67$, and $3.64 \%$ on a DM basis. The FFCG used in this trial was derived from the wet-milling process and contained 3 to $5 \%$ moisture, approximately $44 \%$ ether extract, and approximately $13 \% \mathrm{CP}$ on a DM basis; the fat component contained approximately $56 \%$ linoleic acid, $28 \%$ oleic acid, $11 \%$ palmitic acid, $2 \%$ stearic acid, $1.3 \%$ linolenic acid, and $0.5 \%$ arachidic acid. The fat sources were added such that the fat predominantly replaced corn, and cottonseed hulls and meal were added to the control, TAL, and FFCG diets to balance protein and fiber content with the WCS diet. Cows were housed in tie stalls and were allowed access to an outside lot for $1 \mathrm{~h}$ daily to exercise, in addition to twice-daily trips to the milking parlor. Diets were offered twice daily at 0600 and 1800 $\mathrm{h}$ as a TMR, for ad libitum intake (target of $10 \%$ orts). Amounts of TMR offered and refused were recorded daily. Dry matter $\left(105^{\circ} \mathrm{C}\right.$ for $\left.24 \mathrm{~h}\right)$ of corn silage and wet corn gluten feed were determined weekly and diets were adjusted to maintain proportions of each on a DM basis. Samples of TMR and orts were collected weekly and dried at $105^{\circ} \mathrm{C}$ for $24 \mathrm{~h}$ for $\mathrm{DM}$ determination.

\section{Laboratory Analyses}

Corn silage, alfalfa hay, WCS, wet corn gluten feed, and individual grain mixes were sampled weekly and composited by period for analysis of chemical composition by Northeast DHI Forage Testing Laboratory (Ithaca, NY). Fiber analysis for composites was completed using the Ankom A ${ }^{200}$ (Ankom Technology Corp., Fairport, NY) filter bag technique to measure NDF and ADF. Concentration of CP was completed by combustion analysis (Leco FP-528, Leco, St. Joseph, MI) with protein degradability determined by Streptomyces griseus enzymatic digestion (Roe and Sniffen, 1990; Coblentz et al., 1999). Ether extract was deter- mined gravimetrically after extraction with anhydrous diethyl ether, and NFC was calculated by difference $[\mathrm{NFC}=1-(\mathrm{NDF}+\mathrm{CP}+$ ether extract + ash $)$; NRC, 2001]. Net energy for lactation was calculated using the dairy NRC (2001) computer program from chemical analysis of composites. Cows were weighed and body condition was scored according to a 5-point scale (Wildman et al., 1982) on 2 consecutive days after the morning milking, at the beginning of the study and on d 26 and 27 of each period, and averaged for statistical analysis. Cows were milked twice daily, at 0600 and $1800 \mathrm{~h}$, and milk yield was recorded at each milking. Milk samples were obtained weekly (a.m./p.m. composite), with samples from wk 3 and 4 used for statistical analysis. An additional a.m./p.m. composite milk sample of approximately $30 \mathrm{~mL}$ was collected from each cow on wk 4 of each period for determination of fatty acid profile. Samples of milk were analyzed for fat, protein, lactose, SCC, and MUN content by Heart of America DHI Laboratory (Manhattan, KS). Fat, protein, and lactose contents in milk were determined by using near-infrared spectroscopy (Bentley 2000 Infrared Milk Analyzer, Bentley Instruments Inc., Chaska, MN). A flow cytometer laser (Somacount 500, Bentley Instruments Inc.) was used to determine SCC, and chemical methodology from a modified Berthelot reaction (ChemSpec 150 Analyzer, Bentley Instruments Inc.) was used to measure MUN. The milk sample for fatty acid determination was warmed in a water bath at $38^{\circ} \mathrm{C}$ for $10 \mathrm{~min}$, agitated, and returned to the water bath for 10 additional min. The samples were removed from the water bath, agitated, and 2 separate $200-\mu \mathrm{L}$ subsamples were transferred into $10-\mathrm{mL}$ glass tubes and lyophilized. Fatty acids from the lyophilized samples were derivatized to methyl esters (Bitman et al., 1984) and separated by GLC (model 5890, Hewlett-Packard, Palo Alto, CA) on a $0.25 \mathrm{~mm}$ i.d. $\times 100 \mathrm{~m}$ capillary column with 0.02- $\mu$ m film thickness (SP2560, Supelco Inc., Bellefonte, PA). The injector port temperature was $250^{\circ} \mathrm{C}$ with a split ratio of $100: 1$ and a column flow rate of $1 \mathrm{~mL} / \mathrm{min}$ of $\mathrm{He}$. The initial oven temperature was $140^{\circ} \mathrm{C}$, and was increased to $200^{\circ} \mathrm{C}$ at $2^{\circ} \mathrm{C} / \mathrm{min}$, increased to $240^{\circ} \mathrm{C}$ at $4^{\circ} \mathrm{C} / \mathrm{min}$, and held at $240^{\circ} \mathrm{C}$ for 19 min. A mixture of standard fatty acids (Supelco 37 Component FAME Mix 47885-U, Supelco Inc.) was first analyzed for identification of fatty acids in milk fat, with the methyl ester of C13:0 serving as an internal standard. Detection was completed using a flame-ionization detector with a temperature of $250^{\circ} \mathrm{C}$. Coccygeal blood was collected into 10-mL EDTA Vacutainer tubes (Becton-Dickinson, Franklin Lakes, NJ) at $0900 \mathrm{~h}$ on d 28 of each period. Plasma was harvested and stored at $-20^{\circ} \mathrm{C}$ until analyzed for albumin, NEFA, and urea-N concentrations. Frozen samples were thawed and analyzed for 
MILLER ET AL.

Table 1. Ingredient and nutrient composition of experimental diets

\begin{tabular}{|c|c|c|c|c|}
\hline Item, $\%$ of DM & Control & Whole cottonseed & Tallow & Full-fat corn germ \\
\hline \multicolumn{5}{|l|}{ Ingredient } \\
\hline Alfalfa hay ${ }^{1}$ & 23.05 & 23.01 & 23.00 & 23.08 \\
\hline Corn, ground & 28.42 & 26.87 & 26.89 & 25.74 \\
\hline Wet corn gluten feed & 19.43 & 19.40 & 19.39 & 19.46 \\
\hline Corn silage $^{2}$ & 9.94 & 9.92 & 9.92 & 9.95 \\
\hline Soybean meal, expeller ${ }^{3}$ & 6.99 & 6.98 & 6.98 & 6.98 \\
\hline Fishmeal, menhaden & 1.30 & 1.30 & 1.30 & 1.30 \\
\hline Molasses & 0.97 & 0.97 & 0.96 & 0.90 \\
\hline Cottonseed hulls & 3.31 & - & 3.30 & 3.30 \\
\hline Cottonseed meal & 4.49 & - & 4.48 & 3.52 \\
\hline Whole cottonseed & - & 9.44 & - & - \\
\hline Tallow & - & - & 1.67 & - \\
\hline Full-fat corn germ & - & - & - & 3.64 \\
\hline Sodium bicarbonate & 0.73 & 0.73 & 0.73 & 0.73 \\
\hline Limestone & 0.66 & 0.70 & 0.68 & 0.68 \\
\hline Trace mineralized salt ${ }^{4}$ & 0.31 & 0.31 & 0.31 & 0.31 \\
\hline Magnesium oxide & 0.21 & 0.21 & 0.21 & 0.21 \\
\hline Vitamin ADE premix ${ }^{5}$ & 0.12 & 0.12 & 0.12 & 0.12 \\
\hline Zinpro 4-Plex & 0.05 & 0.05 & 0.05 & 0.05 \\
\hline Sodium selenite premix ${ }^{6}$ & 0.01 & 0.01 & 0.01 & 0.01 \\
\hline \multicolumn{5}{|l|}{ Nutrient } \\
\hline $\mathrm{CP}$ & 18.9 & 18.7 & 18.7 & 18.7 \\
\hline $\mathrm{RDP}$ & 11.4 & 11.9 & 11.4 & 11.3 \\
\hline RUP & 7.5 & 6.8 & 7.4 & 7.4 \\
\hline NDF & 29.7 & 30.0 & 29.5 & 29.9 \\
\hline $\mathrm{ADF}$ & 16.3 & 17.0 & 16.2 & 16.3 \\
\hline $\mathrm{NFC}$ & 42.9 & 41.1 & 41.7 & 41.3 \\
\hline Ether extract & 3.7 & 5.3 & 5.3 & 5.3 \\
\hline Calcium & 0.89 & 0.91 & 0.90 & 0.90 \\
\hline Phosphorus & 0.45 & 0.45 & 0.45 & 0.45 \\
\hline $\mathrm{NE}_{\mathrm{L}},{ }^{7} \mathrm{Mcal} / \mathrm{kg}$ & 1.56 & 1.63 & 1.61 & 1.61 \\
\hline
\end{tabular}

${ }^{1} 22.7 \% \mathrm{CP}, 35.9 \% \mathrm{NDF}$.

${ }^{2} 9.6 \% \mathrm{CP}, 46.2 \% \mathrm{NDF}$.

${ }^{3}$ Soybest (West Point, NE).

${ }^{4}$ Composition: not less than $95.5 \% \mathrm{NaCl}, 0.24 \% \mathrm{Mn}, 0.24 \% \mathrm{Fe}, 0.05 \% \mathrm{Mg}, 0.032 \% \mathrm{Cu}, 0.032 \% \mathrm{Zn}, 0.007 \% \mathrm{I}$, and $0.004 \%$ Co.

${ }^{5}$ Contributed 4,400 IU of vitamin A; 2,200 IU of vitamin D; and 16 IU of vitamin E per kilogram of dietary DM.

${ }^{6}$ Provided $0.06 \mathrm{mg}$ of selenium per kilogram of diet DM.

${ }^{7}$ Calculated using the dairy NRC (2001) computer program from composition of feedstuffs.

albumin (Sigma Albumin Reagent procedure no. 631, Sigma Diagnostics, St. Louis, MO) and NEFA (NEFAC Kit, Wako Chemicals, Richmond, VA; as modified by Eisemann et al., 1988). Plasma urea-N was determined by a diacetyl-monoxime assay using a Technicon Auto Analyzer III (Technicon Industrial Method no. 339-01, Technicon, Tarrytown, NY).

\section{Statistical Analyses}

Data were analyzed as a replicated $4 \times 4$ Latin square with the MIXED procedure (SAS Institute Inc., Cary, $\mathrm{NC}$ ) using the model

$$
Y_{i j k}=\mu+T_{i}+P_{j}+C_{k}+E_{i j k},
$$

where $Y_{i j k}$ is the observation, $\mu$ is the overall mean, $T_{i}$ is the fixed effect of treatment, $P_{j}$ is the fixed effect of period, $C_{k}$ is the random effect of cow, and $E_{i j k}$ is the residual error. Means were separated by use of the $F$ test protected $(P<0.10)$ least significant differences.

\section{RESULTS}

Experimental diets were isonitrogenous (18.7 to $18.9 \%$ CP by analysis; Table 1), and diets containing fat supplements were analyzed to contain similar amounts of ether extract (5.3\%). The control diet with no supplemental fat contained $3.7 \%$ ether extract. The calculated $\mathrm{NE}_{\mathrm{L}}$ were similar for diets containing fat supplements, but were greater than the $\mathrm{NE}_{\mathrm{L}}$ of the control diet because of increased fat content.

Dry matter intake, milk yield, and ECM were similar among diets (Table 2). Efficiency of milk production $(\mathrm{ECM} / \mathrm{DMI})$ was greatest $(P<0.05)$ for cows consuming WCS, whereas TAL or FFCG did not improve 
Table 2. Intake, performance, and plasma metabolites of lactating cows fed diets containing different fat sources

\begin{tabular}{|c|c|c|c|c|c|c|}
\hline Item & Control & Whole cottonseed & Tallow & Full-fat corn germ & SEM & Diet $P$-value \\
\hline Milk, $\mathrm{kg} / \mathrm{d}$ & 40.4 & 40.4 & 40.0 & 41.1 & 0.56 & 0.56 \\
\hline $\mathrm{ECM}, \mathrm{kg} / \mathrm{d}$ & 40.1 & 40.5 & 39.0 & 39.7 & 0.58 & 0.35 \\
\hline Milk fat, $\%$ & $3.42^{\mathrm{ab}}$ & $3.50^{\mathrm{a}}$ & $3.34^{\mathrm{bc}}$ & $3.25^{\mathrm{c}}$ & 0.051 & $<0.01$ \\
\hline Milk protein, $\%$ & $3.14^{\mathrm{a}}$ & $3.09^{\mathrm{b}}$ & $3.08^{\mathrm{b}}$ & $3.08^{\mathrm{b}}$ & 0.013 & $<0.01$ \\
\hline Milk lactose, $\%$ & 4.88 & 4.86 & 4.84 & 4.88 & 0.018 & 0.26 \\
\hline MUN, mg/dL & $16.64^{\mathrm{ab}}$ & $17.11^{\mathrm{a}}$ & $16.29^{\mathrm{b}}$ & $16.30^{\mathrm{b}}$ & 0.21 & 0.02 \\
\hline Initial BCS & 2.69 & 2.75 & 2.72 & 2.74 & 0.38 & 0.47 \\
\hline Initial BW, kg & 701 & 703 & 698 & 700 & 10.4 & 0.65 \\
\hline Change in $\mathrm{BW}, \mathrm{kg}$ & 13.6 & 7.4 & 13.1 & 15.5 & 3.1 & 0.31 \\
\hline \multicolumn{7}{|l|}{ Plasma } \\
\hline $\mathrm{NEFA}, \mu \mathrm{mol} / \mathrm{L}$ & $169^{\mathrm{a}}$ & $154^{\mathrm{a}}$ & $151^{\mathrm{a}}$ & $128^{\mathrm{b}}$ & 6.9 & $<0.01$ \\
\hline
\end{tabular}

${ }^{\mathrm{a}-\mathrm{c}}$ Means within a row not bearing a common superscript letter differ $(P<0.05)$.

the efficiency of ECM relative to the control. Milk fat percentage was less for cows fed FFCG than for those fed the control or WCS diet, but it was similar to milk fat content of cows fed TAL (Table 2). Cows consuming TAL or WCS had milk fat percentages similar to that of cows consuming the control. Yield of milk fat for cows consuming FFCG was similar to that of cows consuming the control or TAL, but was less $(P<0.05)$ than that of cows consuming WCS. Protein content of milk from cows fed the fat supplements was less $(P<$ 0.05) than that of cows fed the control (Table 2), but milk protein yield and lactose contents were not affected by fat supplementation. Greater MUN was observed for cows fed WCS than for those fed FFCG or TAL, and cows consuming FFCG or TAL had MUN content similar to those fed the control. The FFCG significantly decreased plasma NEFA concentrations compared with the other diets (Table 2). Plasma urea-N and albumin concentrations were not different among diets.

Fat supplements decreased the proportions of shortchain fatty acids in milk fat relative to the control, and FFCG decreased medium-chain fatty acid proportions compared with the other 3 diets (Table 3 ). Increased ( $P$ $<0.05$ ) proportions of long-chain fatty acids (LCFA) in milk were observed for all fat-supplemented diets, with cows consuming FFCG having greater $(P<0.05)$ LCFA proportions in milk fat than those fed WCS, which in turn were greater $(P<0.05)$ than those fed TAL. Cows fed FFCG had greater $(P<0.05)$ proportions of total $\mathrm{C}_{18}$ in milk fat than did cows fed the control, WCS, or TAL diet. Total saturated fatty acids in milk fat were decreased $(P<0.05)$ by fat supplementation. In addition, cows consuming FFCG had a lesser proportion $(P$ $<0.05)$ of saturated fatty acids in milk than did cows fed the other fat supplements. In contrast, proportions of unsaturated fatty acids were greater $(P<0.05)$ in milk fat for cows consuming FFCG relative to those consuming the control, WCS, or TAL, and they were greater for cows fed WCS and TAL than for those fed the control. Fat supplementation increased $(P<0.05)$ the proportions of cis-9, trans-11 CLA and its precursor C18:1 trans-11 in milk fat, and cows consuming FFCG had the greatest $(P<0.05)$ proportions of $c i s-9$, trans-11 CLA and C18:1 trans-11 in milk fat.

\section{DISCUSSION}

The purpose of this research was to evaluate the production response of lactating dairy cows to FFCG in comparison with WCS and TAL. Hypophagic effects were not observed when diets with fat supplements were consumed. The lack of effect by fat supplementation on DMI has been observed in previous research (Wu et al., 1993; Pantoja et al., 1996; Avila et al., 2000). In addition, tallow fed at 3 to $5 \%$ of DM in alfalfa-corn silage diets did not affect DMI (Grummer et al., 1993; Drackley et al., 1994). The improved efficiency of milk production by cows fed WCS in our study resulted from a numerical decrease in DMI and a concomitant numerical increase in ECM production.

Milk fat depression has been observed when cows have been fed high-concentrate diets, fat-supplemented diets, or combinations of both (Gaynor et al., 1995; Onetti et al., 2001). Milk fat depression in cows fed FFCG indicates that the corn oil contained within the germ is released more rapidly in the rumen than the oil in WCS. Ruminally unprotected fats may diminish ruminal fiber degradation, decrease acetate production, 
Table 3. Fatty acids present in milk fat from cows fed diets containing different fat sources

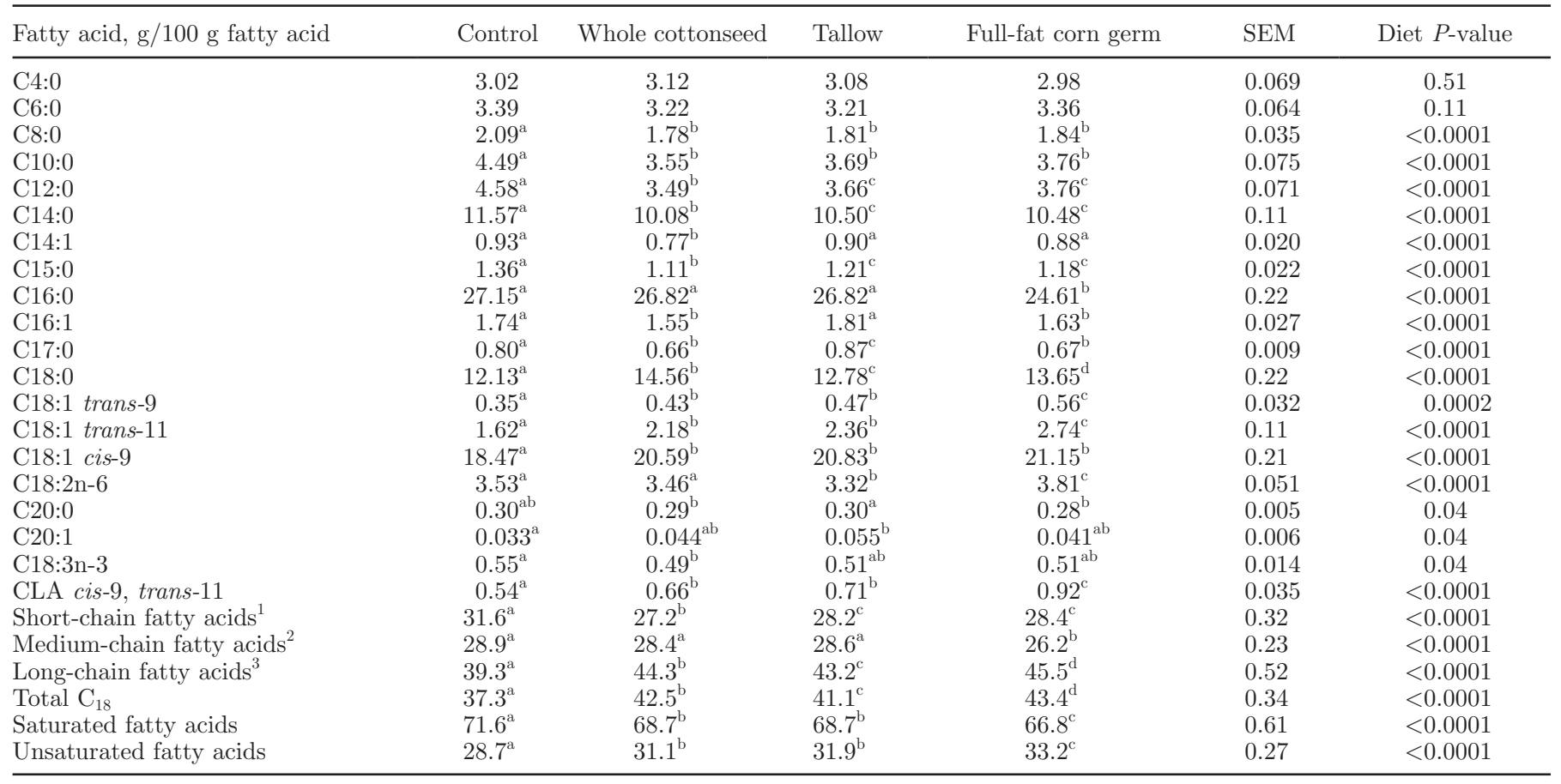

${ }^{\mathrm{a}-\mathrm{d}}$ Means within a row not bearing a common superscript letter differ $(P<0.05)$.

${ }^{1}$ Fatty acids $<\mathrm{C}_{16}$.

${ }^{2} \mathrm{C}_{16}$ fatty acids.

${ }^{3}$ Fatty acids $>\mathrm{C}_{16}$.

and decrease milk fat content (Jenkins, 1993; Palmquist et al., 1993). The linoleic acid content of FFCG approaches $56 \%$ and oleic acid content approaches $28 \%$ of total fatty acids. These fatty acids serve as ruminal precursors for trans-C18:1 fatty acids and trans-10, cis-12 CLA, which have been implicated in milk fat depression (Baumgard et al., 2000, 2002) and may have contributed to the milk fat depression observed when FFCG was included in the diet.

Depression of milk protein content is common when dietary fat is added to the TMR (DePeters et al., 1987; Drackley et al., 2003). Elevated MUN content for cows fed WCS may be the result of greater RDP and lesser RUP concentrations in comparison with other diets. Incorporation of fat into the diets of lactating dairy cows increases the incorporation of LCFA into milk fat while inhibiting de novo synthesis of short-chain and medium-chain fatty acids (Palmquist et al., 1993; Dhiman et al., 1999). Thus, the increase in LCFA is likely due to the increased supply of dietary LCFA available for direct incorporation into milk fat. The reduction in short-chain and medium-chain fatty acids in milk fat from cows fed FFCG in our study was likely due to decreased de novo synthesis in mammary tissue. Linoleic acid in WCS and FFCG provides rumen microbes with a precursor for cis-9, trans-11 CLA and a substrate from which transvaccenic acid can be formed, providing a precursor for de novo synthesis of cis-9, trans-11 CLA in mammary tissue (Abu-Ghazaleh et al., 2002).

\section{CONCLUSIONS}

Full-fat corn germ is a viable energy source for midlactation dairy cows. Full-fat corn germ in the diet supported milk production and protein yield equal to WCS and TAL, but milk fat percentage and fat yield were less for FFCG than for WCS. The addition of FFCG to the diet may decrease circulating NEFA concentrations, but the mechanism is unclear. Milk fatty acid composition is clearly altered by FFCG in a manner that could have positive benefits for human health. Proportions of cis-9, trans-11 CLA in milk fat were increased by approximately $35 \%$, relative to WCS or TAL, when FFCG served as the supplemental fat source. Additional research should be conducted to determine the mechanisms responsible for the observed depression in plasma NEFA, as well as to establish acceptable inclusion levels for FFCG in diets for lactating cows. 


\section{ACKNOWLEDGMENTS}

Funding was provided by Minnesota Corn Processors Inc. (Marshall, MN). Thanks are expressed to the personnel at the Dairy Teaching and Research Unit for their assistance in conducting research trials and to Cheryl Armendariz for her technical assistance in the laboratory. This is contribution number 06-138-J from The Kansas Agricultural Experiment Station (Manhat$\tan , \mathrm{KS})$.

\section{REFERENCES}

Abu-Ghazaleh, A. A., D. J. Schingoethe, A. R. Hippen, and L. A. Whitlock. 2002. Feeding fish meal and extruded soybeans enhances the conjugated linoleic acid (CLA) content of milk. J. Dairy Sci. 85:624-631

Avila, C. D., E. J. DePeters, H. Perez-Monti, S. J. Taylor, and R. A. Zinn. 2000. Influences of saturation ratio of supplemental dietary fat on digestion and milk yield in dairy cows. J. Dairy Sci. 83:1505-1519.

Baumgard, L. H., B. A. Corl, D. A. Dwyer, A. Saebo, and D. E. Bauman. 2000. Identification of the conjugated linoleic acid isomer that inhibits milk fat synthesis. Am. J. Physiol. 278:R179-R184.

Baumgard, L. H., E. Matitashvili, B. A. Corl, D. A. Dwyer, and D. E. Bauman. 2002. Trans-10, cis-12 conjugated linoleic acid decreases lipogenic rates and expression of genes involved in milk lipid synthesis in dairy cows. J. Dairy Sci. 85:2155-2163.

Bitman, J., D. L. Wood, H. F. Tyrrell, C. J. Bouman, C. J. Peel, A. C. G. Brown, and P. J. Reynolds. 1984. Blood and milk lipid responses by growth hormone administration in lactating cows. J. Dairy Sci. 67:2873-2880

Chilliard, Y. 1993. Dietary fat and adipose tissue metabolism in ruminants, pigs, and rodents: A review. J. Dairy Sci. 76:38973931.

Coblentz, W. K., I. E. O. Abdelgadir, R. C. Cochran, J. O. Fritz, W. H. Fick, K. C. Olson, and J. E. Turner. 1999. Degradability of forage proteins by in situ and in vitro enzymatic methods. J. Dairy Sci. 82:343-354.

DePeters, E. J., S. J. Taylor, C. M. Finley, and T. R. Famula. 1987. Dietary fat and nitrogen composition of milk from lactating cows. J. Dairy Sci. 70:1192-1201.

Dhiman, T. R., E. D. Helmink, D. J. McMahon, R. L. Fife, and M. W. Pariza. 1999. Conjugated linoleic acid content of milk and cheese from cows fed extruded oilseeds. J. Dairy Sci. 82:412-419.

Drackley, J. K., T. M. Cicela, and D. W. LaCount. 2003. Responses of primiparous and multiparous Holstein cows to additional energy from fat or concentrate during summer. J. Dairy Sci. 86:13061314.

Drackley, J. K., D. E. Grum, G. C. McCoy, and T. H. Klusmeyer. 1994. Comparison of three methods for incorporation of liquid fat into diets for lactating dairy cows. J. Dairy Sci. 77:1386-1398.

Eisemann, J. H., G. B. Huntington, and C. L. Ferrell. 1988. Effects of dietary clenbuterol on metabolism of the hindquarters in steers. J. Anim. Sci. 66:342-353.

Gaynor, P. J., D. R. Waldo, A. V. Capuco, R. A. Erdman, L. W. Douglass, and B. B. Teter. 1995. Milk fat depression, the glucogenic theory, and trans-C18:1 fatty acids. J. Dairy Sci. 78:2008-2015.

Grummer, R. R. 1988. Influence of prilled fat and calcium salt of palm oil fatty acids on ruminal fermentation and nutrient digestibility. J. Dairy Sci. 71:117-123.

Grummer, R. R., M. L. Luck, and J. A. Barmore. 1993. Rumen fermentation and lactation performance of cows fed roasted soybeans and tallow. J. Dairy Sci. 76:2674-2681.

Jenkins, T. C. 1993. Lipid metabolism in the rumen. J. Dairy Sci. $76: 3851-3863$

Jensen, R. G. 2002. The composition of bovine milk lipids: January 1995 to December 2000. J. Dairy Sci. 85:295-350.

Nocek, J. E. 1997. Bovine acidosis: Implications on laminitis. J. Dairy Sci. 80:1005-1028.

NRC. 2001. Nutrient Requirements of Dairy Cattle. 7th ed. Natl. Acad. Press, Washington, DC.

Onetti, S. G., R. D. Shaver, M. A. McGuire, and R. R. Grummer. 2001. Effect of type and level of dietary fat on rumen fermentation and performance of dairy cows fed corn silage-based diets. J Dairy Sci. 84:2751-2759.

Palmquist, D. L., A. D. Beaulieu, and D. M. Barbano. 1993. Feed and animal factors influencing milk fat composition. J. Dairy Sci $76: 1753-1771$

Pantoja, J., J. L. Firkins, and M. L. Eastridge. 1996. Fatty acid digestibility and lactation performance by dairy cows fed fats varying in degree of saturation. J. Dairy Sci. 79:429-437.

Pereira, M. N. E. F. Garrett, G. R. Oetzel, and L. E. Armentano. 1999. Partial replacement of forage with nonforage fiber sources in lactating cow diets. I. Performance and health. J. Dairy Sci. $83: 2716-2730$.

Roe, M. B., and C. J. Sniffen. 1990. Techniques for measuring protein fractions in feedstuffs. Pages 81-88 in Proc. Cornell Nutr. Conf Feed Manuf., Rochester, NY. Cornell Univ., Ithaca, NY.

Wildman, E. E., G. M. Jones, P. E. Wagner, R. L. Boman, H. F. Troutt Jr., and T. N. Lesch. 1982. A dairy cow body condition scoring system and its relationship to selected production characteristics. J. Dairy Sci. 65:495-501.

Wu, Z., J. T. Huber, F. T. Sleiman, J. M. Simas, K. H. Chen, S. C. Chan, and C. Fontes. 1993. Effect of three supplemental fat sources on lactation and digestion in dairy cows. J. Dairy Sci. $76: 3562-3570$ 